The survey by K. H. Gustavson of the protein chemical aspects of tanning processes gives the reader an interesting and exhaustive account of the present day knowledge of how leather becomes what it is and what it has become.

Proteins, lipids and nucleic acids in cell structures and the known facts about their function and dis. tribution are given in a very readable review by $\mathbf{A}$. Claude. The template theory of protein reproduction has received its latest and well-directed blows from him.

This is a very good volume. The reader, however, has to eope with more than his just share of small errors.

\section{THE UNICORN IN MUSLIM ART}

\section{The Unicorn}

By Richard Ettinghausen. (Freer Gallery of Art. Occasional Papers, Vol. 1, No. 3 : Studies in Muslim Iconography, 1. Smithsonian Publication 3993.) Pp. xii $+209+48$ plates. (Washington, D.C. Smithsonian Institution, 1950.)

THE scope of this monograph is well defined by the title of the series of which it forms the first: all the author's researches into other fields-literature, travels and zoological writings-as also his excursuses into other cultures besides the Islamic, are brought to bear on his primary concern of analysing the iconographic manifestations of the unicorn motif in Muslim art. As he himself frequently emphasizes, the collection of the relevant material in all these many fields is still far from being sufficiently complete to permit an exhaustive treatment of the subject; nevertheless, Dr. R. Ettinghausen's monograph assembles with great erudition the essential part of such material as has to date been made available by the labours of himself and others. In this respect, and also by posing (and only partially answering) certain crucial questions, it may serve to indicate the necessary lines of research on the problem for the future.

The author's powers of exposition, as well as his critical faculties, are unfortunately not equal to his erudition. The work as a whole lacks clear conception, and unnecessary confusion is caused by scattering the treatment of various aspects of a single question in several places throughout the book; moreover, the deficiency extends to important matters of detail - to take only one example, it is, in several instances, virtually impossible to be sure whether the writer is using the term karkadann in the zoological sense of rhinoceros or the mythological sense of unicorn. A typical paragraph of somewhat confused argument, with a dogmatic and practically meaningless conclusion, will be found on p. 71 .

Some parts of the work seem almost a parody of the proverbial 'Teutonic' combination of thoroughness and pointlessness; I would cite the table of confusions and corruptions on p. 43. The possibilities of error, vagueness and exuberant fantasy being limitless in a matter of this kind, it is difficult to see the value of submitting examples to statistical treatment. In this question of karg versus gurg there is a strong savour of the chicken versus egg controversy, but Dr. Ettinghausen might find it useful to take counsel on the vocalization of some of his rhymes as it might have sounded in the original tenth-eleventh century Persian; this would at least have more weight than what even Nöldeke "definitely states". Surely, at least one 'human' explanation of the misplacing of the rhinoceros's horn, even by those who had seen the animal, may be found in distracted alarm at his proximity, coupled with a natural failure to grasp the peculiar shape and set of his head ? In criticizing the average Muslim writer's juxtaposition of contradictory facts (p. 148), the author is probably guilty of an all too common insensitiveness to the immense flexibility of the word 'and' in Arabic, and to the elliptical nature of the language generally.

In respect of typography, bibliography and illustration, the work is produced with a care and magnificence rarely seen in our day. Some half-dozen slips in English constitute only a very minor blemish. Probably the only scholars who will fail to find a large amount of valuable material in this book are zoologists (inevitably), mythologists and those expecting some treatment of the notional and symbolical aspects of the question. G. M. Wickens

\section{THE BIOLOGICAL NATURE OF MAN}

Man is a Microcosm

By J. A. V. Butler. Pp. xii $+152+8$ plates. (London : Macmillan and Co., Ltd., 1950.) 10s. 6d. net.

TOT every man of science is able to write a book 1 which gives a clear and succinct summary, acceptable to the intelligent layman, of a wide field of recent work, most of which is not directly related to the author's own special studies. The writer of such a work has to steer his literary ship between the Scylla of popular pseudo-science and the Charybdis of uncompromising technicalities. In this book, the author has been completely successful in his methods of dealing with biochemistry, embryology and neurology in relation to man.

Dr. J. A. V. Butler has taken as his motto a bon mot of St. John Gogarty, "Stone walls do not a prison make, but scientific terms do" ; and without neglecting the claims of clear scientific English, Dr, Butler has discussed the place of life in the universe. how it may have originated and what is known at present of proteins, enzymes, vitamins, viruses and genes. $\mathrm{He}_{e}$ has shown how the biological scientists of the past few decades have revealed something of the great complexity of the patterns into which the ultimate particles of the universe are woven in living things. When these facts are widely understood, "men may again feel that they are not out of keeping with the splendour of their setting". Thus the book is an attempt at a revaluation of man from the point of view of the biologist. As such, it is an antidote, or at any rate a complement to the ephemeral cosmologies, now in spate, with their partial and often perverse views of the nature of man and his place in the universe.

The illustrations and general production of the book are excellent and its price is reasonable. It can be recommended without reserve to a large group of readers. In particular, it should meet a need for sixth-form 'scientists', specialists in certain subjects who wish to enlarge their field of general study, and students and teachers of biology and medicine who require integrating factors in their studies of living and striving man.

W. L. SuMner 